\title{
O PROCESSO TRADUTÓRIO EM UMA EXPERIÊNCIA DE INTERNACIONALIZAÇÃO DE UM PERIÓDICO BRASILEIRO
}

\author{
THE TRANSLATION PROCESS IN AN EXPERIENCE OF \\ INTERNACIONALIZATION OF A BRAZILIAN JOURNAL
}

\author{
Maryela Bravo RIBEIRO \\ Pesquisadora autônoma \\ Uberlândia, Minas Gerais, Brasil \\ orcid.org/0000-0003-4897-9644 \\ maryela_bravo@hotmail.com
}

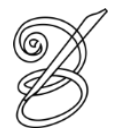

\author{
Igor Antônio Lourenço DA SILVA \\ Universidade Federal de Uberlândia \\ Instituto de Letras e Linguística \\ Bacharelado em Tradução \\ Uberlândia, Minas Gerais, Brasil \\ orcid.org/0000-0003-0738-3262 \\ ials@ufu.br
}

\begin{abstract}
Resumo: Este artigo compreende um breve recorte de uma experiência vivenciada pela primeira autora como tradutora no âmbito de um projeto de internacionalização de um periódico acadêmico, sob supervisão do segundo autor. A experiência foi uma oportunidade de aprendizado sobre as características e os processos editoriais da Revista dos Programas de Pós-Graduação do Instituto de Letras e Linguística da Universidade Federal de Uberlândia, a Letras \& Letras. Inicialmente fomentada pela tradução do sítio eletrônico da revista, que se encontrava apenas em língua portuguesa, a internacionalização tem por objetivo ampliar o fator de impacto da revista ao permitir a atração de autores estrangeiros e a publicação de seus trabalhos em inglês. Na tentativa de promover uma reflexão acerca do aprendizado durante o processo tradutório, são apresentadas análises das traduções realizadas a partir de trechos do sítio eletrônico do periódico, utilizando-se como base uma abordagem funcionalista.
\end{abstract}

Palavras-chave: Processo tradutório. Abordagem funcionalista. Periódico. Internacionalização. Relato de experiência.

Abstract: This article provides a brief overview of the first author's experience as a translator in an internationalization project under the supervision of the second author. The experience was an opportunity of gaining a deeper understanding of the characteristics and editorial processes of a Brazilian academic journal, Letras \& Letras, supported by the graduate programs in Linguistics and Literature at Universidade Federal de Uberlandia. The internationalization process of the journal's website, which was in Brazilian Portuguese only, aimed initially to have it translated in order to broaden the journal's impact factor through the attraction of foreign authors and publications in English. In an attempt to reflect upon what has been learnt during the translation process, this article takes a functionalist approach to analyze some source and translated excerpts from the journal's website.

Keywords: Translation process. Functionalist approach. Journal. Internacionalization. Experience report. 


\section{Introdução}

internacionalização pode ser considerada de grande importância quando se deseja A conquistar um público maior (MESQUITA, 2015); no caso de periódicos, pode mercados por meio da promoção internacional. De acordo com Fernández-Costales (2010, 2012), a tradução, no marco da era global, tornou-se um elemento-chave, tanto no que se refere aos aspectos culturais, sociais e econômicos quanto por razões políticas.

Neste contexto, este artigo apresenta uma reflexão sobre uma experiência de tradução dentro do processo de internacionalização de um periódico da Universidade Federal de Uberlândia, considerando a importância da narrativa humana para esclarecer fenômenos analisados sob uma perspectiva acadêmica (cf. PAIVA, 2008; CONNELLY; CLANDININ, 2006). Parte-se do pressuposto de que a internacionalização de uma revista envolve aspectos que vão além de apenas publicar em inglês, o que a primeira autora pôde vivenciar na prática, por estar inserida, sob orientação do segundo autor (editor do periódico), em um subprograma de Experiência Institucional no âmbito de um Programa de Bolsa de Graduação ${ }^{1}$. Tal projeto 102 visava a contribuições para os processos editoriais e de internacionalização de um periódico e consistiu em uma oportunidade para o aprendizado sobre as características e os processos editoriais da revista dos Programas de Pós-Graduação do Instituto de Letras e Linguística da Universidade Federal de Uberlândia, a Letras \& Letras.

Mais especificamente, trata-se de um encargo de tradução inversa, ou seja, da L1, o português brasileiro, para a L2, o inglês (como lingua franca), o que aumentou a dificuldade da tradutora em avaliar o grau de aceitabilidade da sua tradução. Por não se tratar da sua língua materna e pelo fato de as culturas de chegada serem diferentes daquela em que a tradutora estava inserida, esse encargo poderia, de acordo com Lorenzo (1999), causar certa insegurança e inibir algumas decisões (cf. também DA SILVA et al., 2017). Vale aqui destacar que, por se tratar de uma internacionalização, a noção de cultura de chegada se torna mais difusa, pois o público-alvo é qualquer indivíduo capaz de ler em língua inglesa, independentemente da sua localidade, ou locale (SANDRINI, 2005).

Optou-se por utilizar uma abordagem funcionalista para a análise dos textos-fonte e para a produção e análise dos textos traduzidos. Essa abordagem foca no propósito da tradução, sendo bastante relevante para a localização ou internacionalização de sítios eletrônico, por ter que levar em consideração o público a que se destina, o encargo tradutório, o tipo de texto e o 
objetivo da tradução a fim de se atingir uma comunicação que seja funcional em uma língua diferente.

Sendo assim, este artigo apresenta como se deu o processo de tradução do sítio eletrônico da revista Letras \& Letras e em que medida a primeira versão se diferencia da versão final, esta resultante da interação da tradutora com o cliente (no caso, o editor da revista, segundo autor deste artigo), além de apresentar as principais dificuldades encontradas e a relevância de se utilizar uma abordagem funcionalista, observando-se de que forma essa abordagem pode impactar na tradução. O objetivo geral deste trabalho é refletir sobre o processo de tradução da revista Letras \& Letras, tendo como objetivos específicos: entender a dinâmica da internacionalização da Letras \& Letras; apresentar as etapas do processo de tradução da Revista Letras \& Letras; comparar as versões traduzidas até se obter a versão final; realizar uma análise funcionalista do texto-fonte e do texto traduzido; e fazer um levantamento das principais dificuldades encontradas.

Por se tratar da tradução de um periódico inserido em um programa institucional, houve a participação de mais de um tradutor. Desse modo, a tradução abrangeu partes designadas à primeira tradutora e revisadas pelo próprio cliente.

Este artigo apresenta, em sua totalidade ou parcialmente, as traduções de três seções da revista Letras \& Letras, a saber:

1. trechos do tópico "SUBMISSÕES", acessado através da aba "Normas de Submissão";

2. a parte denominada "FOCO E ESCOPO", acessada através da aba "Sobre", clicando no subitem "Sobre a Revista"; e

3. o rodapé da página da revista, que se encontra na parte inferior do sítio eletrônico.

Todos os textos utilizados foram obtidos por meio do sítio eletrônico: http://www.seer.ufu.br/index.php/letraseletras/index, conforme disponível na versão OJS 3.0. Vale sublinhar que o sítio eletrônico atual apresenta certas divergências em alguns conteúdos e na própria tradução em função de alterações/atualizações geradas na dinâmica da plataforma e de novas necessidades da revista.

\section{Revisão da Literatura}

Em termos tecnológicos, a internacionalização é um pré-requisito para a localização, ou seja, "é uma etapa do processo de desenho e desenvolvimento do produto ou serviço, o que se dá, em geral, antes da localização propriamente dita ou concomitantemente a ela" 
(MESQUITA, 2015, p. 16). Na internacionalização sob essa perspectiva, busca-se fazer com que todo o processo de desenvolvimento seja independente dos recursos específicos de determinando idioma. Assim, segundo a Localization Industry Standards Association (LISA, 2003), torna-se possível remover as particularidades linguísticas de determinado produto, de forma que outro idioma possa ser adicionado ou utilizado em substituição.

É comum utilizar o acrônimo GILT (em inglês), para se referir a globalização, internacionalização, localização e tradução. De acordo com Sandrini (2005), a globalização pode ser entendida como o design global de um produto ou a expansão de mercados, enquanto a internacionalização prepara determinado produto para torná-lo adequado a uma localização eficiente. Por sua vez, a localização pode ser definida como um processo de adaptar mecânica, técnica e linguisticamente para as três grandes áreas atingidas na indústria: software utilitário, software de entretenimento e website. A localização consiste no gerenciamento e manipulação de informações contidas em um produto digital que não se restringem a um componente linguístico. Já a tradução é parte integrante do processo de localização, ou seja:

Visto pela perspectiva dos Estudos da Tradução, entretanto, o processo de tradução envolve transferências [sic] linguísticas e culturais, e a intenção ou função comunicativa do texto-alvo é importante. A tradução, portanto, envolve sempre alguma forma de adaptação [sic] em relação ao próprio texto ou outros itens relevantes para o documento, como gráficos. ${ }^{2}$ (SANDRINI, 2005, p. 132)

Ao se aplicar a noção de internacionalização em periódicos, tem-se um conceito distinto do tecnológico. Nesse caso, busca-se, em vez de localizar um produto para um locale determinado, torná-lo acessível a um público mais amplo, além das fronteiras de um país ou locale. A motivação, pois, é ampliar o potencial de atrair publicações de pesquisadores do exterior, bem como expandir o público leitor para materiais não escritos exclusivamente em língua portuguesa.

A internacionalização de um periódico é um dos indicativos de sua qualidade em tempos atuais. No caso brasileiro, a qualidade de um periódico é classificada de acordo com critérios Qualis da Coordenação de Aperfeiçoamento de Pessoal de Nível Superior (CAPES, 2019), baseados em informações advindas anualmente da plataforma Sucupira.

Para obter ou manter um Qualis elevado, é necessário que haja não apenas uma regularidade na publicação dos volumes, mas sobretudo a inclusão de autores estrangeiros e a publicação de textos de autores brasileiros que tenham sido produzidos diretamente em língua estrangeira ou traduzidos pela língua inglesa, pelo próprio autor ou por outrem, a fim de se 
promover a internacionalização e, assim, promover maior acesso aos artigos e/ou visibilidade da publicação. É notável que os periódicos nacionais têm trabalhado para se tornarem cada vez mais internacionais e, assim, atrair publicações de autores estrangeiros. Para isso, faz-se necessária a divulgação das informações desses periódicos na mesma língua em que se espera receber as submissões.

Como o inglês é tido como lingua franca no meio científico, produzir nessa língua ou traduzir para ela torna-se de extrema importância para a inserção dos pesquisadores brasileiros nos circuitos internacionais de publicação e divulgação científica (VASCONCELOS; SORENSON; LETA; 2007; SILVA; OLIVEIRA; LIMA, 2008; DA SILVA, 2019). Inclusive, a qualidade da escrita em inglês deve ser considerada ao se publicar em periódicos internacionais, uma vez que as habilidades em escrever em outra língua apresentam um papel importante no meio científico (VASCONCELOS; SORENSON; LETA; 2007).

Quando um autor brasileiro decide publicar em língua inglesa um artigo originalmente escrito em português, o que ocorre é a chamada tradução inversa. Como aponta Lorenzo (1999), um aspecto que diferencia a tradução da língua materna para a língua inversa é a dificuldade que o tradutor tem para avaliar o quão aceitável é a sua tradução, ainda mais num contexto em que o público-alvo são falantes ou leitores de língua inglesa de diversas origens. Essa mesma autora supõe que o tradutor profissional tende a se manter dentro dos limites do seu conhecimento e, ao se deparar com alguns desafios tradutórios, prefere não ser muito criativo, utilizando-se da estratégia "play-it-safe", que consistiria em executar (a tradução) da forma mais segura possível.

[...] o tradutor profissional teria que permanecer sempre dentro dos limites do que é conhecido para se sentir confiante em suas decisões, evitando soluções de risco, e diante de novos desafios, recorrer a estratégias de neutralização para transformar o desconhecido em conhecimento e não perder o domínio de seu próprio texto. ${ }^{3}$ (LORENZO, 1999, p.126)

Entre os anos 1960 e 1970, houve grandes debates acerca da noção de equivalência: o texto traduzido estaria íntima e fielmente conectado ao texto em língua estrangeira, e a autonomia da tradução estaria limitada por essa noção de fidelidade e correspondência ao textofonte em termos de palavras e/ou expressões. A partir dos anos 1980, com a difusão das teorias funcionalistas, a noção de equivalência ganha contornos mais difusos, visto que a tradução passa a ser vista como um processo linguístico, social e cultural, em que o texto-fonte e o texto traduzido pertencem a culturas diferentes, devendo, pois, a função de cada um dos textos ser 
levada em consideração, assim como seu público-alvo e o cliente que solicitou o encargo tradutório.

De acordo com Venuti (2004), o conceito de "função vem sendo entendido como o potencial do texto traduzido em revelar diversos efeitos, a começar pela comunicação da informação e pela produção de uma resposta equiparável à produzida pelo texto estrangeiro em sua própria cultura. Sob esse aspecto, o tradutor é considerado o agente responsável pela produção do texto, já que a tradução é uma ação humana dotada de um propósito e reflete em uma escolha consciente do agente.

A abordagem funcionalista de tradução, originalmente desenvolvida entre os estudiosos alemães, visa sistematizar a produção e avaliação das traduções, vinculando funções de linguagem a tipos de texto e estratégia de tradução. Em outras palavras, o texto é visto como um todo e não apenas em partes, sendo a comunicação alcançada no nível do texto a fim de atingir uma tradução funcional para os propósitos a que se destina.

Para Reiss $(2004)^{4}$, a avaliação de uma tradução parte da análise da função principal do texto-fonte (TF), que pode ser informativo, expressivo ou operativo, sendo o tipo textual um 106 fator-chave para a adequação do texto traduzido ao seu público-alvo. Ao levar em consideração o tipo de texto a ser traduzido, o tradutor seria capaz de interpretar o TF e transmitir sua função predominante para o TT, de acordo com o propósito comunicativo da tradução.

Ainda segundo Reiss (2004), a função predominante do texto-fonte é um fator determinante pelo qual o texto traduzido será considerado. Por exemplo, um texto informativo, por apresentar uma comunicação plena dos fatos, deve transmitir a informação por meio de uma linguagem lógica, e sua tradução, assim como a linguagem contida no TF, deve ser sem redundâncias e com o uso de explicações quando necessário. Ou seja, conforme sugere a autora, os métodos de tradução devem ser específicos de acordo com o tipo de texto. Porém, em alguns casos, a autora destaca que nem sempre o TF e o TT terão a mesma função comunicativa, podendo divergir de uma língua para outra. Dependendo do público ao qual a tradução será direcionada, poderá ser necessário analisar a funcionalidade do TT e o contexto da tradução para se atingir o objetivo tradutório.

Outro teórico do funcionalismo é Hans Vermeer (2004), que defende a teoria do Skopos, em que toda ação tem um propósito e leva a um resultado. Na tradução, esse propósito ou objetivo é conhecido pelo termo técnico Skopos, enquanto o resultado da tradução é denominado de Translatum. Segundo Vermeer (2004), o tradutor é o agente responsável pelo 
ato tradutório e necessita de uma especificação precisa do objetivo da tradução, levando-se em consideração o público a que se deseja atingir.

Para essa teoria, o fator considerado decisivo na tradução é o objetivo comunicacional a ser atingido de acordo com a situação, sendo a língua parte de uma cultura. Assim, o textofonte foi escrito para determinada cultura e, ao traduzi-lo, o tradutor não deve apenas transpor esse texto para outra língua, mas, sim, adequá-lo para a cultura-alvo. O tradutor deve ser capaz de explicar suas escolhas e traduzir de forma consciente, gerenciando todo o processo de produção textual. Essa teoria permite que um mesmo texto seja traduzido de várias formas dependendo do objetivo a ser atingindo com o texto traduzido e tendo como foco o leitor do texto final. O que importa não é a fidelidade ao texto-fonte e, sim, se a tradução conseguiu cumprir com seu propósito de maneira apropriada. O Translatum deve sempre ser coerente com a informação extraída do texto-fonte.

“A Teoria do Skopos enfoca, acima de tudo, o propósito da tradução, que determina os métodos e estratégias a serem empregados pelo tradutor para conseguir um resultado funcionalmente adequado" 5 (MUNDAY, 2008, p. 79). Diferentemente da teoria de Reiss, que defende que a medida para avaliar a qualidade da tradução estava no texto-fonte, na teoria do Skopos a tradução é voltada para o próprio texto traduzido.

O modelo de análise proposto por Christiane Nord (1991, 1997, 2016) retoma os conceitos apresentados por Reiss e Vermeer, para, então, apresentar um modelo funcional mais detalhado, incorporando uma análise textual voltada à tradução, em que há a atuação conjunta do TF e do TT. Nord $(1991,2016)$ afirma que deve haver uma análise completa do TF para assegurar uma compreensão total do texto, sendo aplicável a todos os tipos de texto e situações tradutórias. Assim como Vermeer, ela também defende que as estratégias que serão utilizadas dependem do propósito da tradução.

O modelo de Nord $(1991,2016)$ envolve a análise de dois fatores: os extratextuais e os intratextuais. Os fatores extratextuais se referem: à forma como o texto foi produzido e utilizado, incluindo o produtor e o emissor do texto e suas intenções, bem como o receptor; à função textual e ao propósito da produção do texto. Por sua vez, os intratextuais são referentes ao tema, ao estilo e ao conteúdo do texto. Ao considerar esses fatores, o tradutor pode estabelecer a função cultural de um texto-fonte e compará-la com a função do texto-alvo, identificando e isolando esses elementos no texto-fonte que podem ser reinstanciados ou adaptados na tradução. Esses fatores influenciarão o resultado da tradução, podendo interferir 
na intenção e interpretação do texto, bem como no estilo e nas impressões do receptor desse texto.

Nord $(1991,2016)$ afirma também que um mesmo tipo de texto pode apresentar funções distintas em culturas diferentes, ou seja, é o contexto que determinará a função textual e as estratégias a serem adotadas ao se produzir um texto traduzido. Para que um texto consiga comunicar a intenção e o propósito do autor, o TF e o TT devem ser analisados conjuntamente, a fim de que o processo de tradução ocorra de forma funcional.

A tradução é a produção de um texto de destino funcional mantendo um relacionamento com determinado texto de origem que é especificado de acordo com a função pretendida ou exigida do texto de destino (Skopos da tradução). A tradução permite que ocorra um ato comunicativo que, devido às barreiras linguísticas e culturais existentes, do contrário não seria possível. ${ }^{6}$ (NORD, 1991, p. 28)

Desse modo, o processo de tradução estabelece uma comunicação intercultural. Há uma situação comunicativa na qual as estratégias utilizadas pelo autor na produção do TF devem ser analisadas; ao mesmo tempo, os elementos do TF deverão ser adequados ao 108 propósito comunicativo do leitor da tradução, respeitada a intenção do autor e devendo haver a produção de uma tradução funcional e adequada às necessidades do iniciador (proponente), caso haja.

Outro modelo funcionalista foi proposto por Holz-Mänttäri (1984) e denominado de teoria da ação tradutória. Considerando a tradução uma interação humana guiada por objetivos a fim de se atingirem resultados, esse modelo enfoca o processo de tradução como uma forma de transmitir mensagens, envolvendo a transferência intercultural. Em outras palavras, a tradução de uma língua para outra é entendida como um processo comunicativo que envolve diferentes agentes a partir de um texto-fonte, sendo orientada de acordo com seu propósito. Para Holz-Mänttäri (1984), os agentes envolvidos na ação tradutória são: o iniciador (proponente), o cliente ou comissário, o produtor do texto-fonte, o produtor do texto traduzido, o usuário do TT e o receptor do TT. Essa teoria se concentra na produção de um texto traduzido que seja funcionalmente adequado para o receptor, levando em consideração a cultura do TT.

Sendo assim, entende-se que, antes de iniciar qualquer tradução, o tradutor deve analisar o texto como um todo, a fim de melhor compreender o texto-fonte e garantir uma comunicação efetiva com os receptores do texto traduzido. 


\section{Metodologia}

O acesso ao conteúdo da revista foi concedido pelo editor da revista. Optou-se por copiar o conteúdo manualmente no MS Word, em arquivos referentes a cada aba do periódico, por se tratar de um portal em que os conteúdos em língua inglesa precisariam ser inseridos manualmente pelo editor. Em outras palavras, não seria possível utilizar uma ferramenta de localização de website porque não traria grandes benefícios ao tipo de encargo tradutório.

Após obtenção do conteúdo da revista, cada seção foi inserida no Wordfast Pro 3, no qual houve a criação de um projeto com memória compartilhada por um servidor WF Server, servidor esse instalado por um técnico da equipe de informática do Instituto de Letras e Linguística. Assim, seria possível ter acesso aos glossários e às revisões feitas em tempo real, visto que outra tradutora participou do projeto.

As seções do sítio eletrônico a serem traduzidas foram divididas entre as duas tradutoras, somente sendo possível obter uma versão final com a padronização de termos e linguagem por meio da utilização de memória compartilhada em servidor, criada na ferramenta WordFast Pro 3. Vale destacar que, no presente trabalho, somente são apresentadas as comparações das versões e a versão final de traduções feitas pela autora.

Uma vez concluída cada etapa da tradução, foi gerada automaticamente uma tabela bilíngue, através do próprio Wordfast Pro 3. Essa tabela, com o texto-fonte à direita e o textoalvo à esquerda, foi usada para revisão pelo editor do periódico.

Para que fosse possível a tradução do periódico, primeiramente foi feita uma leitura do conteúdo em português, bem como a criação de um glossário com os termos mais recorrentes e específicos. Em um segundo momento, a tradução do sítio eletrônico foi feita a partir da utilização de vários dicionários eletrônicos e impressos, corpora (e.g., COCA e ANC); também foram feitas consultas frequentes a sítios eletrônicos de outros periódicos (e.g., UC Berkeley Comparative Literature Undergraduate Journal ${ }^{7}$ ), com o intuito de se familiarizar com a linguagem utilizada nesse meio. Finalmente, após a tradução de cada seção, a proposta era apresentada ao editor, que fazia a revisão e mandava seus comentários e sugestões de melhorias, para, assim, se chegar a um consenso e obter a versão final que seria publicada.

As comparações das versões traduzidas serão apresentadas em tabelas contendo: o texto-fonte, a primeira versão e a versão final, lado a lado, para poder apontar os problemas mais recorrentes e as alterações implementadas ao longo do processo. Nesse sentido, tecem-se comentários acerca das escolhas utilizadas na primeira versão, bem como se apresentam as modificações mais relevantes ao longo do processo tradutório. 
Com base em uma abordagem funcionalista, analisam-se os textos-fonte, que foram escolhidos de acordo com o seu tipo, dois textos informativos e um operativo, bem como se identificam os atores desse processo tradutório. Também se faz uma reflexão acerca do aprendizado durante esse processo, a partir da experiência da primeira autora na prática da internacionalização da revista, visando melhorar a sua atuação como tradutora.

\section{Análise dos dados}

Consoante os apontamentos de Holz-Mänttäri (1984), a teoria da ação tradutória parte de um texto-fonte e envolve diversos atores (iniciador/proponente, cliente/comissário, produtor do TF, produtor do TT, usuário do TT e o receptor do TT) para que haja uma comunicação orientada funcionalmente, trespassando as barreiras culturais. Analisando o processo de tradução da revista Letras \& Letras e aplicando essa teoria, é possível identificar os agentes envolvidos na ação tradutória.

Foi identificada como proponente (i.e., iniciador, a empresa ou o indivíduo que necessita da tradução) a Universidade Federal de Uberlândia - mais especificamente

110 representada na figura da Editora da UFU (EDUFU). Já o cliente, que seria o indivíduo que entra em contato com o tradutor, foi o editor do periódico. O único agente que não foi possível identificar foi o produtor do texto-fonte, uma vez que não se identificou ao certo quem o produziu, embora se saiba que minimamente houve influência dos últimos editores. No papel de produtora do texto traduzido, houve a atuação da tradutora, que neste caso se refere à primeira autora deste artigo. Os usuários do texto traduzido foram identificados como os editores da revista e o corpo editorial - neste caso, são as pessoas que fazem uso do texto traduzido, no sentido de utilizarem do TT para atrair um público estrangeiro. Por fim, o destinatário final foi identificado como os autores e leitores da revista, denominados por HolzMattari (1984) de receptores do texto traduzido (TT) - que são aqueles a quem de fato a tradução se destina.

Holz-Mattari (1984) afirma ainda que o tradutor tem o papel de determinar o que é funcionalmente adequado na cultura do texto traduzido, por ser o responsável em garantir que a 'transferência' intercultural ocorra de forma satisfatória. O texto-fonte deveria ser analisado de acordo com os aspectos relevantes de conteúdo e forma, tendo as necessidades dos autores e leitores da revista como os fatores determinantes para o TT.

Para que a tradução do sítio eletrônico da revista se tornasse funcionalmente comunicativa para os seus leitores e pudesse atender ao objetivo de atrair mais publicações de 
autores estrangeiros, fez-se necessário pensar em todos os agentes envolvidos bem como no contexto sociocultural da tradução. Nesse âmbito, a teoria da ação tradutória foi usada como diretriz para cada decisão tomada pela tradutora.

O interesse da revista na tradução do seu portal parte da necessidade de se internacionalizar, objetivando melhorar sua visibilidade no âmbito internacional e promover a própria revista, para, assim, atrair autores estrangeiros e aumentar o número de publicações em outra língua. Desse modo, utilizando o conceito da teoria do Skopos de Vermeer, o propósito da tradução da revista é sua internacionalização, tendo como público-alvo os autores e leitores da revista.

No decorrer de todo o processo de tradução, houve o contato com o editor da revista, que explicou a intenção do texto de partida e quais as estratégias deveriam ser adotadas a fim de se produzir o texto de chegada com a devida interpretação. $\mathrm{O}$ editor também forneceu todas as diretrizes necessárias para que as tradutoras conseguissem priorizar quais as informações deveriam ser inclusas no texto traduzido, como, por exemplo, as funções pretendidas de cada texto e para quem seria dirigido o texto em língua estrangeira. Desse modo, segundo Nord (1997), o texto traduzido, ao satisfazer o Skopos, delineado pelo cliente, seria considerado funcional e comunicativamente adequado.

Das traduções feitas para o sítio eletrônico do periódico, foram selecionados três textos-fonte e suas traduções para análise. O primeiro texto a ser analisado consiste em trechos retirados do tópico "NORMAS DE SUBMISSÃO", acessado através da aba "Submissões" da página eletrônica da revista, como mostra a Figura 1. 
Figura 1 - Menu "Submissões" do sítio eletrônico da Letras \& Letras

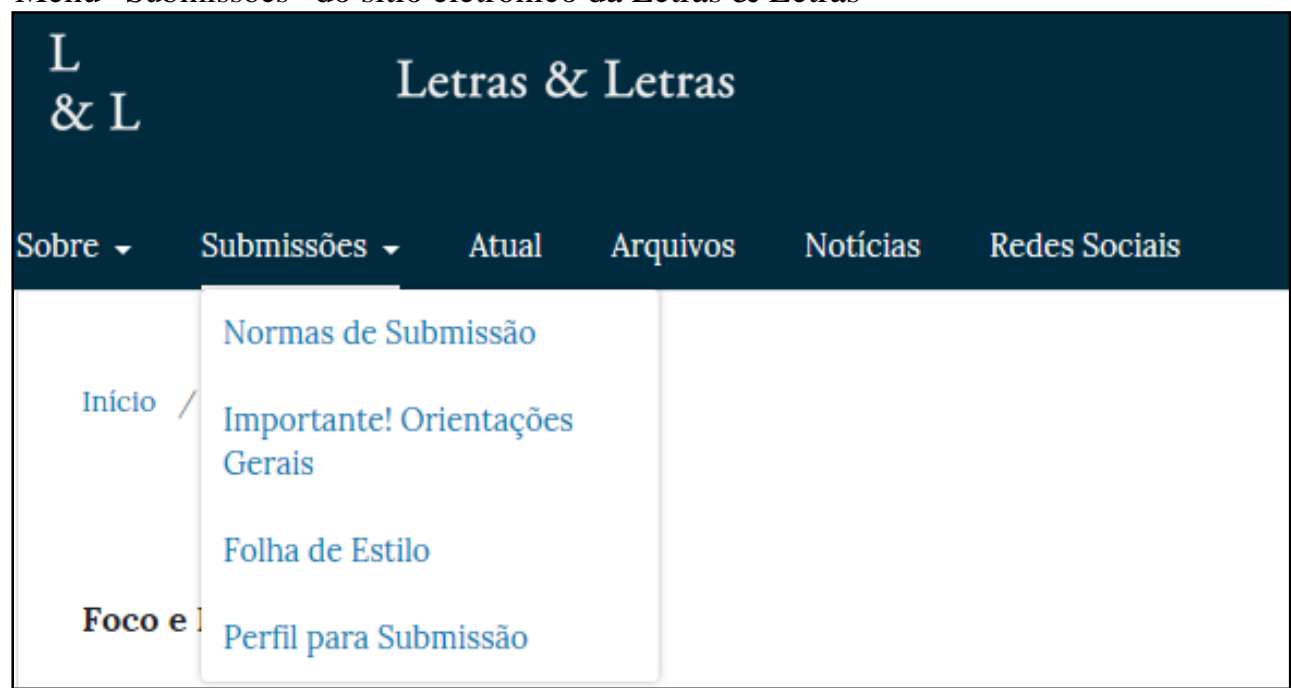

Fonte: instantâneo do sítio eletrônico da Letras \& Letras. Disponível em: http://www.seer.ufu.br/index.php/letraseletras/about/submissions. Acesso em: 25 jun. 2019.

A partir da teoria funcionalista de Reiss (2004), em que os textos deveriam ser identificados de acordo com a função principal do texto-fonte, verificou-se que o primeiro texto

112 apresenta a função de texto operativo, por persuadir o receptor do texto a agir de determinado modo. Assim, na tradução desse texto operativo, tentou-se manter um efeito similar ao do TF, preservando-se a semântica, como pode ser verificado no Quadro 1.

Quadro 1 - Proposta de tradução para "Das normas para a Apresentação dos Originais"

\begin{tabular}{|c|c|c|}
\hline \multicolumn{1}{|c|}{ TEXTO-FONTE } & $\begin{array}{c}\text { TEXTO TRADUZIDO } \\
\text { (sem revisão) }\end{array}$ & \multicolumn{1}{c|}{ TEXTO FINAL } \\
\hline $\begin{array}{c}\text { DAS NORMAS PARA A } \\
\text { APRESENTAÇÃO DOS } \\
\text { ORIGINAIS }\end{array}$ & $\begin{array}{c}\text { RULES FOR THE } \\
\text { PRESENTATION OF THE } \\
\text { ORIGINALS }\end{array}$ & $\begin{array}{c}\text { RULES FOR MANUSCRIPT } \\
\text { SUBMISSION }\end{array}$ \\
\hline $\begin{array}{l}\text { 1. A Revista Letras \& Letras } \\
\text { aceita trabalhos somente } \\
\text { de pós-graduandos stricto } \\
\text { sensu e mestrado profissional, }\end{array}$ & $\begin{array}{l}\text { 1. Letras \& Letras accepts } \\
\text { works only from graduate } \\
\text { students, master and PhD. }\end{array}$ & $\begin{array}{l}\text { 1. Letras \& Letras accepts } \\
\text { manuscripts from graduate } \\
\text { students, or holders of master's } \\
\text { or doctoral degree. }\end{array}$ \\
\hline $\begin{array}{l}\text { doutores e livre-docentes. pós- } \\
\text { de um permitida a publicação } \\
\text { co-autor (es) em cada número } \\
\text { da revista. }\end{array}$ & $\begin{array}{l}\text { 2. Author(s) or co-author(s) } \\
\text { are allowed to publish one } \\
\text { article per issue. }\end{array}$ & $\begin{array}{l}\text { 2. Only one manuscript } \\
\text { submission is allowed for each } \\
\text { author or coauthor in each call } \\
\text { for papers. }\end{array}$ \\
\hline $\begin{array}{l}\text { 3. Cada trabalho submetido à } \\
\text { revista não pode contar com } \\
\text { mais de três autores. }\end{array}$ & $\begin{array}{l}\text { 3. Each work submitted to the } \\
\text { journal can not have more than } \\
\text { three authors. }\end{array}$ & $\begin{array}{l}\text { 3. No more than three } \\
\text { researchers can coauthor a } \\
\text { manuscript. }\end{array}$ \\
\hline
\end{tabular}

Elaboração: os autores 
Na terceira linha do Quadro 1, entendeu-se, já na primeira versão da tradução, que seria desnecessário, em língua inglesa, evidenciar uma diferenciação entre pós-graduação stricto sensu e lato sensu e entre acadêmica e profissional. Também se entendeu que não existe o título de pós-doutor e que, mesmo que houvesse, tanto pós-doutores e livre-docentes deveriam ter o doutorado. Na quarta linha do Quadro 1, optou-se, na versão final, por "call for papers" em vez de "número", porque, após interação com o editor, ficou-se sabendo que há pesquisadores que acabam submetendo mais de um trabalho para o mesmo número a fim de conseguir que pelo menos um seja publicado; assim, optou-se pela redação final no intuito de evitar processos editoriais desnecessários (e.g., o acionamento de vários pareceristas para um artigo que, mesmo aprovado, não poderá ser publicado em razão de já haver outro do mesmo autor).

Além disso, partindo do pressuposto de que o público-alvo consiste, no caso do texto acima, nos autores do periódico, deve haver uma integração entre esse público e a revista. Para que isso ocorra, é necessário o uso de uma linguagem em que o conteúdo seja compreendido sem ambiguidades ou diferentes interpretações. Por exemplo, na tabela acima, traduziu-se inicialmente "trabalho" e "artigo" pelos seus respectivos correspondentes formais "work" e "article"; no entanto, buscando-se maior coesão e coerência no texto, decidiu-se, ao final, traduzir ambos os termos por um único, "manuscripts". Entendeu-se que "works" é genérico demais, podendo se referir a uma obra (como um todo), a um livro inteiro ou mesmo a trabalhos não escritos (embora, claro, o próprio contexto possa resolver essa ambiguidade), enquanto "articles" era restrito demais, referindo-se apenas a um dos tipos de textos aceitos pela revista (outros incluíram, por exemplo, resenhas, traduções comentadas e ensaios). Assim, visando à coesão e coerência, decidiu-se - após consulta à página de outros periódicos - por um único termo, "manuscript", que corresponde à versão de um artigo ou qualquer outro material escrito anterior à sua publicação. Em outras palavras, a palavra "manuscript" foi repetida no decorrer da tradução a fim de padronizar a linguagem e, ao mesmo tempo, deixar em aberto o tipo de trabalho escrito que poderia ser submetido ao periódico.

Outro exemplo da necessidade de consistência a fim de manter a coesão e coerência do texto pode ser visto no trecho a seguir, em que "textos" também foi traduzido por "manuscripts" na versão final: 
Quadro 2 - Proposta de tradução para trecho de "Normas de Submissão"

\begin{tabular}{|l|l|l|}
\hline \multicolumn{1}{|c|}{ TEXTO-FONTE } & \multicolumn{1}{|c|}{$\begin{array}{c}\text { TEXTO TRADUZIDO } \\
\text { (sem revisão) }\end{array}$} & \multicolumn{1}{c|}{ TEXTO FINAL } \\
\hline $\begin{array}{l}\text { Os textos deverão estar } \\
\text { acompanhados de resumo e } \\
\text { palavras-chave (no idioma do } \\
\text { texto) e de abstract e } \\
\text { keywords em inglês. }\end{array}$ & $\begin{array}{l}\text { The texts must include } \\
\text { abstract and keywords in } \\
\text { English. }\end{array}$ & $\begin{array}{l}\text { All manuscripts must include } \\
\text { an abstract and keywords in the } \\
\text { original language and in } \\
\text { English. }\end{array}$ \\
\hline $\begin{array}{l}\text { No caso de textos em inglês, } \\
\text { deverão estar acompanhados } \\
\text { de resumo e palavras-chave em } \\
\text { português. }\end{array}$ & $\begin{array}{l}\text { In case of the texts in English, } \\
\text { they must be accompanied by } \\
\text { an abstract and keywords in } \\
\text { Portuguese. }\end{array}$ & $\begin{array}{l}\text { English-language manuscripts } \\
\text { must necessarily include an } \\
\text { abstract and keywords in } \\
\text { Portuguese. Editors can } \\
\text { provide them upon acceptance } \\
\text { if necessary. }\end{array}$ \\
\hline
\end{tabular}

Elaboração: os autores

No Quadro 2, pelo fato de o texto-fonte estar dirigido apenas ao público falante da língua portuguesa, havia a necessidade de especificar que "abstract" e "keywords" deveriam vir em inglês. Ao traduzir esse trecho, a tradutora considerou que, como o texto em inglês seria direcionado a um público estrangeiro, não haveria a necessidade de repetir a informação, visto

114 que "abstract" já é a tradução para "resumo" na língua inglesa. Porém, a pedido do cliente, entendeu-se que o texto no inglês não se destina somente aos falantes dessa língua, sendo um meio de atingir falantes de outras línguas, inclusive aqueles que publicariam em francês ou espanhol, línguas aceitas pelo periódico. Assim, na versão final ficou especificado que todas as submissões deveriam conter resumo e palavras-chave independentemente do idioma, acrescidas do abstract e das keywords em inglês.

Ademais, em conversa com o cliente, ficou claro que a revista tinha interesse pela produção de autores internacionais em língua inglesa, não devendo a tradução do resumo e das palavras-chave para o português constituir um empecilho às suas submissões. Nesse sentido, adicionou-se uma informação ao texto: eles poderão ser fornecidos pelos próprios editores caso sejam aceitos.

Esses dois exemplos ilustram como a necessidade do receptor é um fator determinante ao se produzir um TT. Além disso, a possibilidade de ter contato com o cliente e entender sua real necessidade permitiu que houvesse uma interpretação mais assertiva da intenção do emissor do texto.

No decorrer do projeto foi possível conhecer mais a fundo as reais necessidades do cliente, entender suas especificidades e o propósito da tradução, podendo, assim, tornar o TT 
mais adequado ao objetivo da revista de atrair mais publicações de autores estrangeiros. Isso também é evidenciado no Quadro 3.

Quadro 3 - Proposta de tradução para "Condições para Submissão"

\begin{tabular}{|c|c|c|}
\hline TEXTO-FONTE & $\begin{array}{l}\text { TEXTO TRADUZIDO } \\
\text { (sem revisão) }\end{array}$ & TEXTO FINAL \\
\hline $\begin{array}{l}\text { CONDIÇÕES PARA } \\
\text { SUBMISSÃO }\end{array}$ & $\begin{array}{l}\text { SUBMISSION } \\
\text { PREPARATION } \\
\text { CHECKLIST }\end{array}$ & SUBMISSION CHECKLIST \\
\hline $\begin{array}{l}\text { Como parte do processo de } \\
\text { submissão, os autores são } \\
\text { obrigados a verificar a } \\
\text { conformidade da submissão em } \\
\text { relação a todos os itens listados a } \\
\text { seguir. }\end{array}$ & $\begin{array}{l}\text { As part of the submission } \\
\text { process, authors are required } \\
\text { to verify compliance of the } \\
\text { submission regarding all } \\
\text { items listed below: }\end{array}$ & $\begin{array}{l}\text { As part of the submission } \\
\text { process, authors are required } \\
\text { to ensure compliance with the } \\
\text { conditions below. }\end{array}$ \\
\hline $\begin{array}{l}\text { As submissões que não estiverem } \\
\text { de acordo com as normas serão } \\
\text { devolvidas aos autores. }\end{array}$ & $\begin{array}{l}\text { Submissions that do not } \\
\text { comply with the standards } \\
\text { will be returned to the authors. }\end{array}$ & $\begin{array}{l}\text { Submissions that do not } \\
\text { comply with the guidelines } \\
\text { will be returned to the authors. }\end{array}$ \\
\hline
\end{tabular}

Elaboração: os autores

Nesse exemplo, a primeira versão do texto traduzido sofreu poucas intervenções em sua revisão (texto final). Talvez a alteração mais importante nesse exemplo seja o uso do verbo "verify", que remete à comprovação de algo, quando, na verdade, se tratava de uma checagem ou averiguação; daí a versão final contar com o verbo "ensure". Ademais, vale reiterar que o tipo texto também determinou as escolhas da tradutora em relação às negativas para os casos de auxiliares, como "do not", assim como para os casos de verbos modais, como "can not" (cf. Quadro 1).

Nord $(1991,2016)$ afirma que o texto-fonte pode ser analisado para decidir sobre as prioridades funcionais da estratégia de tradução, levando-se em consideração os fatores intratextuais, que se referem ao próprio texto, e os fatores extratextuais, que se referem à situação na qual foi produzido. O trecho do Quadro 4 foi extraído da seção "Diretrizes para Autores", que fornece informações sobre o que os autores devem seguir para que consigam publicar na revista. Ainda que as diretrizes geralmente remetam a textos operativos, neste caso se encontrou uma parte que era informativa, como pode ser observado na terceira linha do Quadro 4. Trata-se especificamente de uma informação sobre a não cobrança de valores para submissão e publicação no periódico.

RIBEIRO, Marvela Bravo; DA SILVA, Igor Antônio Lourenço. O processo tradutório em uma experiência de internacionalização de um periódico brasileiro. Belas Infiéis, Brasília, v. 9, n. 4, p. 101-125, jul./set., 2020. 
Quadro 4 - Texto-fonte e proposta de tradução para "Diretrizes para Autores"

\begin{tabular}{|l|l|l|}
\hline \multicolumn{1}{|c|}{ TEXTO-FONTE } & \multicolumn{1}{c|}{$\begin{array}{c}\text { TEXTO TRADUZIDO } \\
\text { (sem revisão) }\end{array}$} & TEXTO FINAL \\
\hline DIRETRIZES PARA AUTORES & \multicolumn{1}{|c|}{ AUTHOR GUIDELINES } & AUTHOR GUIDELINES \\
\hline $\begin{array}{l}\text { Não há custos para os autores } \\
\text { na submissão e publicação de } \\
\text { seus artigos na revista Letras } \\
\text { \& Letras. }\end{array}$ & $\begin{array}{l}\text { There are no costs for authors } \\
\text { to submit and publish their } \\
\text { articles in Letras \& Letras } \\
\text { magazine. }\end{array}$ & $\begin{array}{l}\text { Submitting and publishing are } \\
\text { free of charge for authors. }\end{array}$ \\
\hline
\end{tabular}

Elaboração: os autores

Na primeira versão, optou-se por uma tradução palavra por palavra, aqui entendida como uma tradução em que há forte correspondência formal entre os elementos do texto-fonte e do texto traduzido (e.g., "Não há" "There are no", em que há correspondência formal entre os advérbios de negação "Não" e "no" e entre os verbos "há" e "[there] be"). Inclusive, traduziu-se "revista" como "magazine" (geralmente, publicação periódica destinada ao público em geral), e não "journal" (neste contexto, uma publicação especializada). No entanto, na última versão, optou-se por uma comunicação mais sucinta em língua inglesa, buscando-se uma mensagem que fosse, no entendimento dos agentes envolvidos, mais clara e objetiva. Para tal, 116 entendeu-se que era desnecessária a menção ao nome do periódico, que já estaria claro no contexto em que o texto-alvo se encontraria. Além disso, colocaram-se os processos de submeter e publicar em posição temática e optou-se por uma formulação positiva, em vez de negativa. Em tendo adotado tais procedimentos, a tradutora obteve textos com funções similares, embora sem correspondência formal entre cada elemento do texto-fonte e do textoalvo.

O segundo texto selecionado para análise encontra-se na parte denominada "FOCO E ESCOPO", que pode ser acessada também através da aba "Sobre", clicando-se no subitem "Sobre a Revista", como mostra a Figura 2. 
Figura 2 - Menu "Sobre” do sítio eletrônico da Revista Letras \& Letras

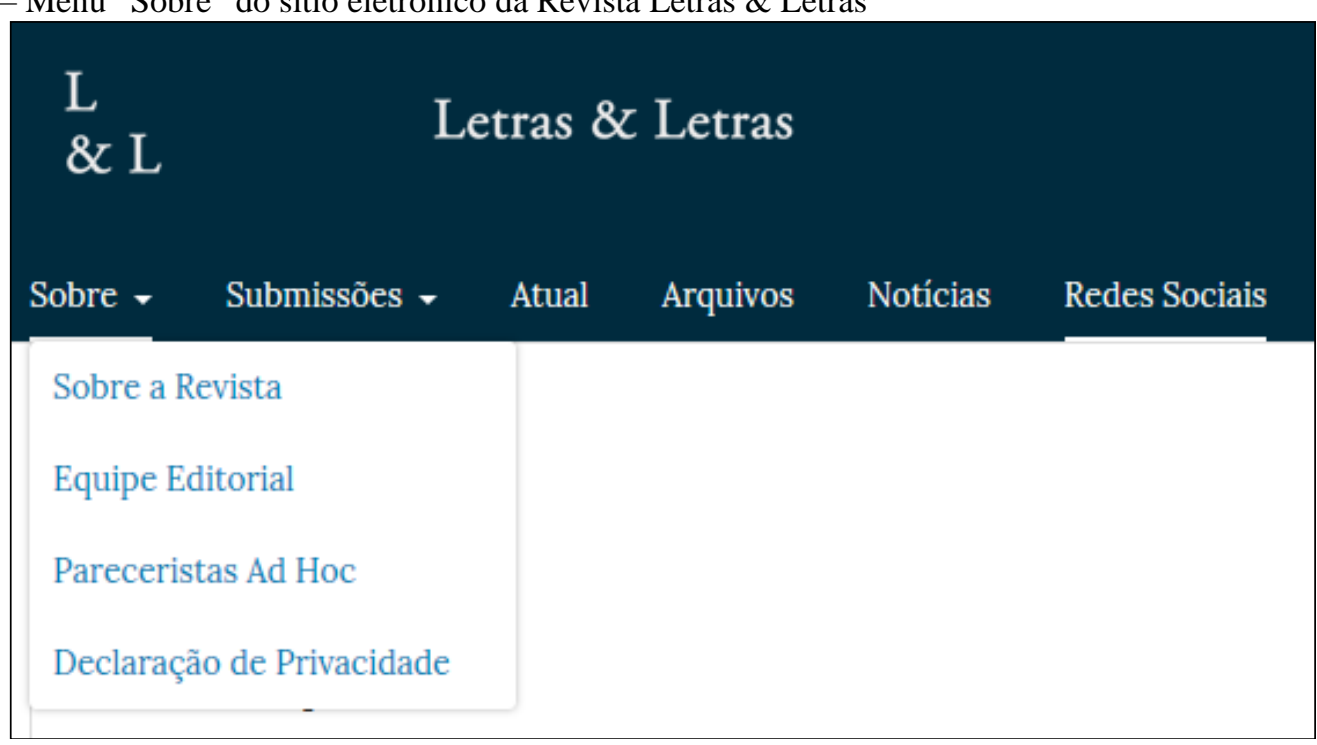

Fonte: instantâneo do sítio eletrônico da Revista Letras \& Letras. Disponível em: www.seer.ufu.br/index.php/letraseletras/about. Acesso em: 02 mar. 2020.

Assim como o primeiro, esse texto também foi analisado conforme a abordagem funcionalista de Reiss (1984). Observou-se que o texto-fonte é informativo, pois traz informações acerca da revista e tem por objetivo apresentá-la a seus leitores.

Logo na segunda linha do Quadro 5, pode-se verificar que o título "foco e escopo" foi traduzido em um primeiro momento, porém foi omitido em sua versão final após passar por uma revisão. Entendeu-se que essa informação não era necessária ao público-alvo, uma vez que a aba do menu inicial da página, intitulada de "sobre a revista" já havia sido traduzida. Sendo assim, a tradução visou garantir aos receptores apenas as informações relevantes, como o que é a revista e qual o seu foco. Essa decisão foi tomada juntamente com o cliente, que ajudou a priorizar quais informações deveriam ser inclusas no TT. 
Quadro 5 - Texto-fonte e proposta de tradução para "Foco e Escopo"

\begin{tabular}{|l|l|l|}
\hline \multicolumn{1}{|c|}{ TEXTO-FONTE } & \multicolumn{1}{|c|}{$\begin{array}{c}\text { TEXTO TRADUZIDO } \\
\text { (sem revisão) }\end{array}$} & \multicolumn{1}{c|}{ TEXTO FINAL } \\
\hline \multicolumn{1}{|c|}{ FOCO E ESCOPO } & \multicolumn{1}{c|}{ FOCUS AND SCOPE } \\
\hline $\begin{array}{l}\text { A Revista Letras \& Letras é } \\
\text { editada em volumes anuais } \\
\text { compostos por dois números, } \\
\text { publicados em separado a cada } \\
\text { semestre e disponibilizados } \\
\text { apenas pela Internet. }\end{array}$ & $\begin{array}{l}\text { Letras \& Letras is edited in } \\
\text { annual volumes, composed of } \\
\text { two issues, separately } \\
\text { published each semester, } \\
\text { available online only. }\end{array}$ & $\begin{array}{l}\text { Letras \& Letras is a biannual } \\
\text { journal available on the } \\
\text { Internet only. }\end{array}$ \\
\hline $\begin{array}{l}\text { Ambos os números são } \\
\text { temáticos e propostos pelas } \\
\text { linhas de pesquisa dos } \\
\text { programas de pós-graduação } \\
\text { do ILEEL. }\end{array}$ & $\begin{array}{l}\text { Both issues are thematic and } \\
\text { proposed by the research areas } \\
\text { of the Graduate Program of } \\
\text { the institute (ILEEL). }\end{array}$ & $\begin{array}{l}\text { Both issues are thematic and } \\
\text { revolve around theories, } \\
\text { reflections and methods in the } \\
\text { field of Linguistics, Literature } \\
\text { and Translation. }\end{array}$ \\
\hline
\end{tabular}

Elaboração: os autores

Na terceira linha do Quadro 5, pode-se notar, na última versão, o uso de uma frase mais curta, primando por uma maior objetividade nas informações e evitando redundâncias. No texto-fonte, tem-se toda uma explicação acerca da periodicidade da revista; na primeira versão

118 da tradução, a mesma sequência de informações foi seguida, inclusive no que diz respeito aos correspondentes formais. Todavia, no texto final, toda informação contida no TF foi traduzida de forma mais objetiva, utilizando-se a palavra "biannual" para resumir maior parte da explicação contida no TF. Entendeu-se que essa informação sucinta já bastava para um texto veiculado em meio eletrônico e para um público leitor acostumado com as separações entre números e volumes no âmbito dos periódicos acadêmicos.

Já na quarta linha, a tradução teve de ser adequada ao receptor final, visto que os autores e leitores estrangeiros desconhecem o que seja a sigla ILEEL (Instituto de Letras e Linguística), que por si só já poderia ser desconhecida de muitos brasileiros que nunca tiveram algum contato com a unidade acadêmica. Nesse caso, pensou-se em apresentar uma explicitação para a sigla ou simplesmente usar a estratégia de omissão, retirando o nome da instituição. Como em outro lugar já havia a informação de que a Letras \& Letras é uma revista dos programas de pós-graduação e como, pela proposta do editor, a internacionalização da revista também implicaria que pessoas de outros programas pudessem propor volumes temáticos, o que, contudo, ainda não estava formalizado no momento, optou-se por explicitar as principais áreas de atuação dos docentes do ILEEL: linguística, literatura e tradução. O texto traduzido aparece no sítio eletrônico da revista conforme ilustrado na Figura 3. 
Figura 3 - Menu "About the Journal” do sítio eletrônico da Letras \& Letras

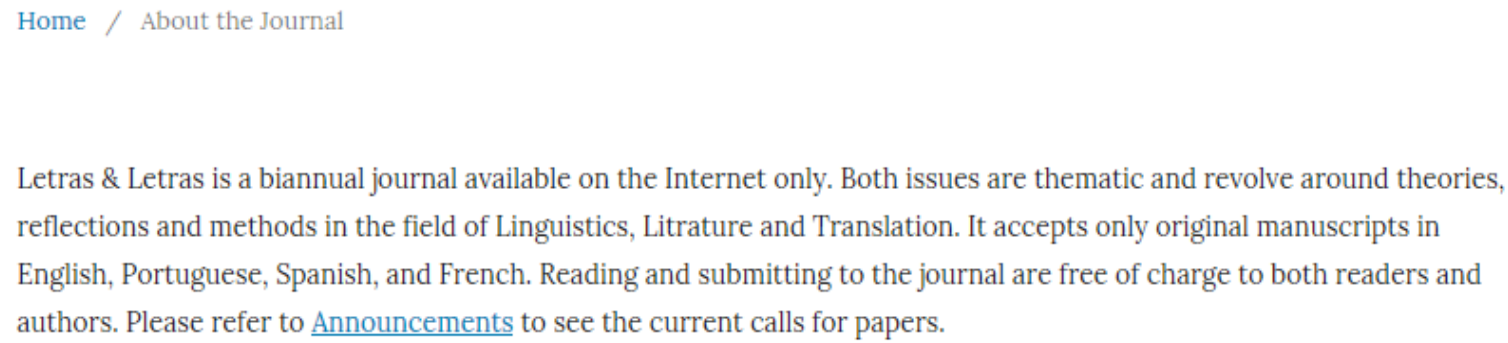

Fonte: instantâneo do sítio eletrônico da Revista Letras \& Letras. Disponível em: www.seer.ufu.br/index.php/letraseletras/about. Acesso em: 02 mar. 2020.

Como aponta Munday (2008), se o texto traduzido cumpre o objetivo proposto pelo cliente, torna-se funcional e comunicativamente adequado. Em outras palavras, as pressuposições acerca do receptor do texto de chegada determinaram a inclusão ou não de certas informações, mas, ao mesmo temo, buscou-se obedecer ao propósito informativo do texto.

Em vez de estabelecer normas para a produção de um texto 'equivalente' em língua estrangeira, a análise do texto-fonte antes da tradução oferece uma base para uma comparação entre as informações do TF e o que se pretende alcançar no TT. Essa comparação serve para identificar problemas e formar estratégias de tradução que permitirão superar os obstáculos, atingindo as funções comunicativas desejadas para o TT, sempre em conformidade com o que o cliente espera da tradução. Nord (1997) deixa evidente que o método de tradução adotado depende de fatores que podem ir além do tipo textual, como o contexto sociocultural, o público a que se destina, o tempo e o espaço, bem com o objetivo da tradução e os elementos nãoverbais.

O terceiro e último texto a ser analisado é o rodapé da página da revista, que se encontra na parte inferior do portal (http://www.seer.ufu.br/index.php/letraseletras), conforme a Figura 4.

Figura 4 - Rodapé do sítio eletrônico da Letras \& Letras - Versão em Português

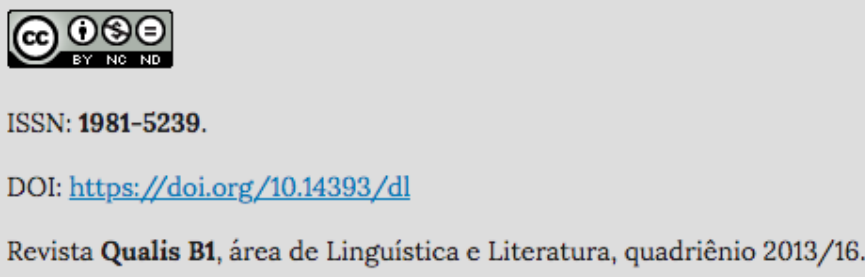

Fonte: instantâneo do sítio eletrônico da Revista Letras \& Letras. Disponível em: www.seer.ufu.br/index.php/letraseletras/about. Acesso em: 02 mar. 2020. 
Trata-se também de um texto informativo, uma vez que transmite uma informação acerca da revista para seus autores e leitores. O propósito deste texto é informar aos receptores a qualidade atingida pela revista, classificada de acordo com critérios Qualis da CAPES.

No processo de tradução da página, optou-se por retirar essa informação acerca do Qualis B1 (referente ao quadriênio 2013/16 e adotada no sistema antigo de classificação da CAPES), por entender que o público-alvo, no caso os autores estrangeiros, não estariam familiarizados com o termo. Caso fosse mantida essa informação, deveria ser acrescida uma explicação sobre o que é o Qualis.

São as necessidades do receptor que determinam como se dará o TT. Dessa forma, para manter a coesão no que diz respeito à terminologia, essa nomenclatura, se mantida, precisaria ser esclarecida para um usuário do TT não familiarizado com ela. A informação é relevante para os autores brasileiros, que conhecem o Qualis e julgam sua classificação quando do envio de manuscritos. Ao selecionar a opção "English" no menu à direita, o texto traduzido aparece como na Figura 5.

120 Figura 5 - Rodapé do sítio eletrônico da Letras \& Letras - Versão em Inglês

ISSN: 1981-5239.

DOI: https://doi.org/10.14393/dl

Fonte: instantâneo do sítio eletrônico da Revista Letras \& Letras. Disponível em: www.seer.ufu.br/index.php/letraseletras/about. Acesso em: 02 mar. 2020.

A omissão foi feita a pedido do cliente, que é o comissário da ação tradutória, por entender que a informação não influenciaria na decisão do público-alvo em publicar um artigo na revista, visto que os autores estrangeiros desconhecem o significado de Qualis. Nesse trecho, a função do texto-fonte não se aplica à função estrangeira do público que se deseja atingir, sendo o conteúdo irrelevante na comunicação com os receptores do texto. Assim, na versão traduzida da página da revista, em seu rodapé, a frase contendo "Revista Qualis B1" não aparece por perder o seu significado em outros locales.

As diferenças culturais requerem uma atenção maior por parte do tradutor, que deve tentar entendê-las a fim de se produzir um texto de chegada adaptável à(s) cultura(s) a que se destina. Em outras palavras, nem sempre o que funciona em uma determinada língua irá funcionar em outra. 
No decorrer do processo de tradução do periódico, vários problemas e dúvidas em relação à tradução foram surgindo, sendo necessários a adoção de estratégias e o contato com o cliente para elaborar um plano específico visando resolver os problemas detectados.

Portanto, após a análise dos textos selecionados, tanto o TF como o TT, foi possível entender que, do ponto de vista das teorias funcionalistas, toda tradução tem um propósito, o qual determinará o modo como deve ser realizada a tradução. Além disso, o contexto cultural, o tipo de texto e os agentes envolvidos também determinarão as estratégias a serem utilizadas na produção do texto traduzido a fim de que a comunicação interlinguística seja atingida.

\section{Considerações Finais}

Este artigo buscou refletir sobre a inserção da tradutora no processo de internacionalização da Letras \& Letras. Essa internacionalização seria inicialmente fomentada pela tradução do sítio eletrônico do periódico para a língua inglesa, haja vista que se encontrava apenas em língua portuguesa. Ao se publicar em outra língua - mais especificamente, o inglês, hoje configurado como língua franca no meio científico -, tinha-se como objetivo primário ampliar o fator de impacto da revista, pois assim se permitiria a inclusão de parecerista e autores estrangeiros. Esperava-se com isso elevar, no médio prazo, o Qualis da revista, que foi classificada como B1 (quadriênio 2013-2016), o que poderia vir a ser viabilizado a partir da ampliação do público leitor e, consequentemente, das citações em outras publicações, a partir da atração de membros estrangeiros para o seu corpo editorial e a partir do aumento no número de submissões em língua estrangeira por autores também de instituições estrangeiras.

A primeira atividade realizada no Projeto PBG 412 (Contribuições para os processos editoriais e de internacionalização de um periódico) foi o aprendizado sobre as características e os processos editoriais da revista Letras \& Letras; também houve o estudo de ferramentas computacionais de apoio à tradução / localização / internacionalização de websites, sobretudo aquelas relativas ao WordFast Pro 3. Em seguida, seções da revista foram selecionadas para que a tradução do sítio eletrônico da revista fosse realizada; ao término de cada tradução, o material era enviado ao orientador/editor para então ser validado. Foi utilizada uma memória de tradução compartilhada em servidor, além do intercâmbio de ideias, descobertas, achados, recomendações e sugestões com o orientador e com a outra colaboradora voluntária. Ademais, foram feitas reuniões periódicas com o orientador. A tradução de parte das informações contidas no sítio eletrônico da Letras \& Letras já se encontra publicada em http://www.seer.ufu.br/index.php/letraseletras. 
Foi através do referido projeto que a primeira autora teve a oportunidade de vivenciar na prática a experiência editorial, em que o professor orientador/editor da revista atuou como cliente real e todas as traduções foram realizadas de acordo com as suas necessidades e demandas. Atuar de forma colaborativa com a aluna voluntária, também no papel de tradutora, e ter um revisor final e um cliente com suas demandas específicas tornou o processo parecido com situações reais do mercado de trabalho. O diferencial dessa experiência estava no fato de que, através das revisões feitas, os erros mais recorrentes eram apontados, sendo possível aprender por meio de discussões com o orientador no que diz respeito às escolhas tradutórias em língua estrangeira, aprimorando as habilidades tradutórias de todos os envolvidos.

Uma das dificuldades encontradas no decorrer de todo o processo de internacionalização do periódico foi no que se refere aos elementos não verbais, por haver limitações na localização do website. Originalmente, não era possível localizar o portal, visto que o texto em língua inglesa era apresentado logo abaixo do texto em português, não havendo uma localização propriamente dita e não sendo possível transpor nem substituir todo o conteúdo do sítio eletrônico ao selecionar a opção de visualizar "English". Tinha-se uma plataforma sem 122 praticidade nesse sentido, não havendo meios de acessá-la e torná-la adequada à cultura de chegada. Somente recentemente foi que esse processo se modificou; agora, já é possível visualizar o sítio eletrônico em uma única língua, seja ela inglês ou português, a depender da escolha do leitor, autor ou parecerista ao selecionar a língua desejada no menu localizado do lado direito da página.

Outro aspecto que deve ser mencionado é o fato de a tradução desses textos ser uma tradução inversa, do português (L1 das tradutoras) para o inglês (sua L2), o que dificultou ainda mais o trabalho das tradutoras envolvidas. À medida que a atividade foi ocorrendo, foi-se adquirindo familiaridade com o tema e agregando conhecimento, o que, de certa forma, foi diminuindo a complexidade da tarefa gradualmente e dando mais confiança às envolvidas, que puderam entregar um produto final com qualidade e que cumprisse as exigências do cliente.

Optou-se por utilizar um modelo funcionalista na análise dos textos, a fim de melhor compreender o processo tradutório e conseguir soluções mais adequadas ao se considerar o escopo da tradução. Sendo assim, essa abordagem tornou o processo de tradução dos textos mais coerente, na medida em que evidenciou todos os atores envolvidos na tradução e especificou o propósito do texto-fonte e do texto traduzido. Ademais, foi possível sustentar decisões fundamentas no que diz respeito a omissões, adições e explicitações de conteúdo. De fato, nota-se que o sítio eletrônico em inglês não é um "espelho" do português no que diz 
respeito ao seu conteúdo, até porque seu público-alvo tem necessidades diferentes e está inserido em culturas distintas daquele falante de língua portuguesa no Brasil. Portanto, ao fazer uma análise mais aprofundada do texto-fonte e colocar o tradutor como o agente responsável por suas decisões, devendo ser capaz de justificar suas escolhas tradutórias, a comunicação em língua estrangeira torna-se mais eficiente, uma vez que será necessário pensar em estratégias específicas para cada tipo de texto e de acordo com o público a que se deseja atingir.

Por fim, vale mencionar que este artigo compreende um breve recorte da experiência vivenciada pela tradutora e pelo orientador no âmbito de um projeto de internacionalização. Trabalhos futuros poderão avaliar melhor a inserção do conteúdo na própria página, as modificações que se farão necessárias ao longo do tempo (por questões de atualização ou mesmo de feedback dos usuários) e a coesão e coerência de todo o conjunto textual, considerando-se os hyperlinks e diferentes caminhos que um usuário pode tomar ao acessar uma página do portal do periódico.

\section{REFERÊNCIAS}

CAPES. Aprimoramento do processo de avaliação da pós-graduação. Disponível em: http://capes.gov.br/images/novo_portal/documentos/DAV/avaliacao/18072019_Esclareciment os_Qualis2.pdf?fbclid=IwAR3pPlbyguROJujg3ATC-VASRs1_2-WJOxOIkZFZRhUCTtRwzhRZ3kwddc. Acesso em: 02 mar. 2020.

CONNELLY F. Michael, CLANDININ, D. Jean. Narrative Inquiry. In: GREEN, Judith L., CAMILLI, Gregory; ELMORE, Patricia B (Ed.). Handbook of complementary methods in education research. Mahwah, NJ: Lawrence Erlbaum, 2006, p. 375-385.

DA SILVA, Igor A. Lourenço. An interactional expertise-based approach to specialized inverse translation. Tradução em Revista (online), v. 26, p. 86-98, 2019. https://doi.org/10.17771/PUCRio.TradRev.40528

DA SILVA, Igor A. Lourenço; ALVES, Fabio; SCHMALTZ, Marcia; PAGANO, Adriana S.; WONG, Derek; CHAO, Lidia; LEAL, Ana Luísa V.; QUARESMA, Paulo; GARCIA, Caio; SILVA, Gabriel E. Translation, post-editing and directionality. In: JAKOBSEN, Arnt L.; MESA-LAO, Bartolomé (Ed.). Translation in transition: Between cognition, computing and technology. Amsterdam: John Benjamins, 2017, p. 108-134. https://doi.org/10.1075/btl.133.04lou

DA SILVA, Igor A. Lourenço; OLIVEIRA, Maria Luisa; LIMA, Kelen C. Sant'Anna. Conhecimento experto em tradução: uma abordagem processual e discursiva de tarefas tradutórias realizadas por pesquisadores expertos. Revista da Abralin, v. 7, p. 279-312, 2008. https://doi.org/10.5380/rabl.v7i1.52619

RIBEIRO, Marvela Bravo; DA SILVA, Igor Antônio Lourenço. O processo tradutório em uma experiência de internacionalização de um periódico brasileiro. Belas Infiéis, Brasília, v. 9, n. 4, p. 101-125, jul./set., 2020. 
FERNÁNDEZ-COSTALES, Alberto. The internationalization of institutional websites: the case of universities in the European Union. In: PYM, Anthony; ORREGO-CARMONA, David (Ed.). Translation research projects. Tarragona: Intercultural Studies Group, 2012. p. 51-60.

FERNÁNDEZ-COSTALES, Alberto. Traducción, localización e internacionalización: el caso de las páginas web universitarias. 2010. 552 f. Tese (Doutorado em Tradução) - Departamento de Filología Anglogermánica y francesa, Universidad de Oviedo, Oviedo, 2010.

HOLZ-MÄNTTÄRI, Justa. Translatorisches Handeln: Theorie und Methode. Helsinki: Suomalainen Tiedeakatemia, 1984.

LISA, Localization Industry Standards Association. The localization industry primer. 2. ed. Féchy: SMP Marketing and the LISA, 2003.

LORENZO, María Pilar. La seguridad del traductor professional en la traducción a una lengua extranjera. In: HANSEN, G. (Ed.). Probing the process in translation: methods and results. Copenhagen Studies in Language. Copenhague: Samfundslitteratur, v. 24, p. 21-134, 1999.

MESQUITA, Leonardo Penha. Tradução comentada de um site universitário e tutorial para uso de uma ferramenta tecnológica de apoio à tradução. 2015. 80 f. Monografia (Graduação em Tradução) - Instituto de Letras e Linguística, Universidade Federal de Uberlândia, Uberlândia, 2015.

MUNDAY, Jeremy. Functional theories of translation. In: MUNDAY, Jeremy. Introducing translation studies: theories and applications. 2. ed. London and New York: Routledge, 2008. p. 71-88. https://doi.org/10.4324/9780203869734

NORD, Christiane. Análise textual em tradução: bases teóricas, métodos e aplicação didática. Coordenação da tradução e adaptação de Meta Elisabeth Zipser. São Paulo: Rafael Copetti Editor, 2016.

NORD, Christiane. Translating as a purposeful activity: functionalist approaches explained. Manchester: St Jerome, 1997.

NORD, Christiane. Text Analysis in translation: theory, methodology, and didactic application of a model for translation-oriented text analysis. Translated from the German by Christiane Nord and Penelope Sparrow. Amsterdam: Rodopi, 1991.

PAIVA, Vera Lúcia Menezes. A pesquisa narrativa: uma introdução. Revista Brasileira de Linguística Aplicada, Belo Horizonte, v. 8, n. 2, p. 261-266, 2008. Disponível em: http://www.scielo.br/scielo.php?script=sci_arttext\&pid=S1984-

63982008000200001\&lng=en\&nrm=iso. Acesso em: 2 mar. 2020. https://doi.org/10.1590/S1984-63982008000200001

REISS, Katharina. Type, kind and individuality of text: decision making in translation. Translated by Susan Kitron. In: VENUTI, Lawrence (Ed.). The translation studies reader. New York: Routledge: 2004. p. 160-171. 
SANDRINI, Peter. Website localization and translation. In: MUTRA CONFERENCE, Saarbrücken, 2-6 maio 2005. Proceedings... Saarbrücken: MuTra, 2005. p. 131-138.

VASCONCELOS, Sonia M. R.; SORENSON, Martha M.; LETA, Jacqueline. Scientistfriendly policies for non-native English-speaking authors: timely and welcome. Brazilian Journal of Medical and Biological Research, Ribeirão Preto, v. 40, p. 743-747, 2007. https://doi.org/10.1590/S0100-879X2007000600001

VENUTI, Lawrence. Introduction. In: VENUTI, Lawrence (Ed.). The translation studies reader. New York: Routledge, 2004. p. 1-18.

VERMEER, Hans-Josef. Skopos and commission in translational action. Translated by Andrew Chesterman. In: VENUTI, Lawrence (Ed.). The translation studies reader. New York: Routledge, 2004. p. 221-232.

\footnotetext{
${ }^{1}$ Programa de Bolsas de Graduação 2017, com o Projeto 412 - Contribuições para os processos editoriais e de internacionalização de um periódico. Foi desenvolvido de 01 de setembro de 2017 a 30 de junho de 2018.

2 Tradução da autora para: "Seen from a translation studies perspective, however, the process of translation involves linguistic as well as a cultural transfer and the communicative intention or function of the target text is of overall importance. Translation, therefore, always involves some form of adaptation with respect to the text itself or other items relevant to the document such as graphics."

${ }^{3}$ Tradução da autora para: "[...] el traductor professional tendría a mantenerse simpre dentro de los limites de lo conocido para sentirse seguro de sus decisiones, evitando soluciones arriesgadas, y que ante nuevos desafios recurriría a estrategias de neutralizacion para convertir en conocido lo desconocido y no perder el dominio del próprio texto."

${ }^{4}$ A não menção a correntes funcionalistas não alemães não implica qualquer tipo de crítica ou desmerecimento.

5 Tradução da autora para: "Skopos theory focuses above all on the purpose of the translation, which determines the translation methods and strategies that are to be employed in order to produce a functionally adequate result."

${ }^{6}$ Tradução da autora para: "Translation is the production of a functional target text maintaining a relationship with a given source text that is specified according to the intended or demanded function of the target text (translation skopos). Translation allows a communicative act to take place which because of existing linguistic and cultural barriers would not have been possible without it."

${ }^{7}$ UC Berkeley Comparative Literature Undergraduate Journal. Disponível em: https://ucbcluj.org/. Acesso em: 02 mar. 2020.
}

\section{NOTA DOS AUTORES}

Maryela Bravo RIBEIRO - Bacharel em Tradução (2019) pela Universidade Federal de Uberlândia. Pesquisadora autônoma. Uberlândia, Minas Gerais, Brasil.

ORCID: https://orcid.org/0000-0003-4897-9644

Currículo acadêmico: http://lattes.cnpq.br/8073534514385848

E-mail: maryela_bravo@hotmail.com

Igor A. Lourenço DA SILVA - Professor adjunto na Universidade Federal de Uberlândia. Membro permanente dos Programas de Pós-graduação em Estudos Linguísticos da Universidade Federal de Minas Gerais (POSLIN) e da Universidade Federal de Uberlândia (PPGEL). Doutor (2012) e Mestre (2007) em Estudos Linguísticos pela Universidade Federal de Minas Gerais. Licenciado (2004) e Bacharel (2003) em Letras - Inglês pela mesma instituição. Universidade Federal de Uberlândia, Instituto de Letras e Linguística, Bacharelado em Tradução. Uberlândia, Minas Gerais, Brasil.

ORCID: https://orcid.org/0000-0003-0738-3262

Currículo acadêmico: http://lattes.cnpq.br/6440150670404908

E-mail: ials@ufu.br

RIBEIRO, Marvela Bravo; DA SILVA, Igor Antônio Lourenço. O processo tradutório em uma experiência de internacionalização de um periódico brasileiro. Belas Infiéis, Brasília, v. 9, n. 4, p. 101-125, jul./set., 2020.

e-ISSN: 2316-6614. DOI: doi.org/10.26512/belasinfieis.v9.n4.2020.27338 